\title{
Fatigue assessment of welded joints using multiaxial fatigue space theory with nominal stress approach
}

\author{
Chun $\mathrm{Lu}^{1}$, Jiliang $\mathrm{Mo}^{1}$, and Hongqin Liang ${ }^{1}$ \\ ${ }^{1}$ Southwest Jiaotong University
}

November 27, 2020

\begin{abstract}
Welded joints are widely employed in engineering field and they are always the starting points of fatigue damage. Because of the unfavorable material and geometry characters, as well as initial welding defects, the fatigue damage evaluation of welded joints is an important and troublesome issue for engineers. In this article, multiaxial fatigue space theory proposed by the first author for smooth specimens is extended for the fatigue damage assessment of welded joints, by adopting nominal stress approach. The fatigue test data with different materials, loading paths, and welded joints geometries are used to validate the capability of this theory. The result indicates a strong parallelization between predicted life and experimental life, with a favorable prediction error and beneficial error distribution. It can be concluded that multiaxial fatigue space theory is a useful method for fatigue damage assessment of welded joints with the help of nominal stress approach.
\end{abstract}

\section{Hosted file}

main document.pdf available at https://authorea.com/users/367130/articles/495581-fatigueassessment-of-welded-joints-using-multiaxial-fatigue-space-theory-with-nominal-stressapproach

\section{Hosted file}

Table 1.pdf available at https://authorea.com/users/367130/articles/495581-fatigueassessment-of-welded-joints-using-multiaxial-fatigue-space-theory-with-nominal-stressapproach

\section{Hosted file}

Figure 1.pdf available at https://authorea.com/users/367130/articles/495581-fatigueassessment-of-welded-joints-using-multiaxial-fatigue-space-theory-with-nominal-stressapproach

\section{Hosted file}

Figure 2.pdf available at https://authorea.com/users/367130/articles/495581-fatigueassessment-of-welded-joints-using-multiaxial-fatigue-space-theory-with-nominal-stressapproach

\section{Hosted file}

Figure 3.pdf available at https://authorea.com/users/367130/articles/495581-fatigueassessment-of-welded-joints-using-multiaxial-fatigue-space-theory-with-nominal-stressapproach

\section{Hosted file}


Figure 4.pdf available at https://authorea.com/users/367130/articles/495581-fatigueassessment-of-welded-joints-using-multiaxial-fatigue-space-theory-with-nominal-stressapproach

\section{Hosted file}

Figure 5.pdf available at https://authorea.com/users/367130/articles/495581-fatigueassessment-of-welded-joints-using-multiaxial-fatigue-space-theory-with-nominal-stressapproach

\section{Hosted file}

Figure 6.pdf available at https://authorea.com/users/367130/articles/495581-fatigueassessment-of-welded-joints-using-multiaxial-fatigue-space-theory-with-nominal-stressapproach

\section{Hosted file}

Figure 7.pdf available at https://authorea.com/users/367130/articles/495581-fatigueassessment-of-welded-joints-using-multiaxial-fatigue-space-theory-with-nominal-stressapproach

\section{Hosted file}

Figure 8.pdf available at https://authorea.com/users/367130/articles/495581-fatigueassessment-of-welded-joints-using-multiaxial-fatigue-space-theory-with-nominal-stressapproach

\section{Hosted file}

Figure 9.pdf available at https://authorea.com/users/367130/articles/495581-fatigueassessment-of-welded-joints-using-multiaxial-fatigue-space-theory-with-nominal-stressapproach

\section{Hosted file}

Figure 10.pdf available at https://authorea.com/users/367130/articles/495581-fatigueassessment-of-welded-joints-using-multiaxial-fatigue-space-theory-with-nominal-stressapproach 